Volume 02 Nomor 02, Desember 2020 Page 26-36

Incrementapedia: Jurnal Pendidikan Anak Usia Dini

Program Studi PG-PAUD Fakultas Pedagogik dan Psikologi

Universitas PGRI Adi Buana Surabaya

http://jurnal.unipasby.ac.id/index.php/incrementapedia

e-ISSN: 2686-3146

\title{
HUBUNGAN ANTARA KEMAMPUAN BERSENAM DENGAN KEMAMPUAN MENARI \\ PADA ANAK USIA DINI KELOMPOK USIA 5-6 TAHUN TK AISYIYAH BUSTANUL ATHFAL 57 SURABAYA
}

\author{
Ahmad Fachrurrazi ${ }^{1}$, Oka Alfira Eka Mulya Damayanti ${ }^{2}$ \\ ${ }^{1,2}$ PG-PAUD Fakultas Pedagogik dan Psikologi Universits PGRI Adi Buana Surabaya \\ email: ahmadfachrurrazi@unipasby.ac.id
}

\begin{abstract}
This study aims to determine the relationship between the ability to exercise with the ability to dance in early childhood group b aged 5-6 years TK Aisyiyah Bustanul Athfal 57 Surabaya. Ability is a potential for a person or individual to master expertise in doing or doing various tasks in a job or an assessment of someone's actions. Gymnastics is an activity that can stimulate physical-motor development in early childhood. Through gymnastics activities, it is hoped that other abilities or intelligences can also develop properly and can make children who are healthy, smart, cheerful and have character. Meanwhile, dancing is a feeling conveyed through beautiful rhythmic movements. This study uses a quantitative approach with a correlation research design with Product Moment correlation. Data were collected using participatory observation techniques. The results of data analysis show that the value of rcount is 0.973 . While the rtable index was 0.4227 for the 0.05 significance level, and 0.5368 for the 0.01 significance level with $N=20$. Thus hypothesis $0($ hO) is rejected so that the working hypothesis $(h 1)$ is accepted. The r-count value $=0.973$ is in the range of 0.800 to 1.00 , including in the high correlation category between variable $x$ and variable y.It can be concluded that there is a relationship between the ability to exercise and the ability to dance in early childhood group B aged 5-6 years at TK Aisyiyah Bustanul Athfal 57 Surabaya. The relationship between the two variables is a symmetrical relationship, meaning that if one variable increases, the other variable also increases. Thus it can be said that there is a strong relationship between the ability of gymnastics to dance. This may imply that the better the child's exercise skills, the better the ability to dance.
\end{abstract}

Keywords: Gymnastics Ability, Dancing Ability.

\section{PENDAHULUAN}

Pendidikan pada anak usia dini pada dasarnya terdiri atas semua tindakan yang dilakukan oleh guru maupun orang tua untuk menstimulasi pertumbuhan serta perkembangan anak dengan memberikan kebebasan serta kesempatan pada anak untuk menggali pengalaman di lingkungan dengan sendirinya secara langsung untuk menumbuhkan potensi dan kecerdasan anak. Setiap anak memiliki potensi yang berbeda-beda dari satu anak dengan anak yang lain, sesuai dengan tahapan perkembangan dan pertumbuhan yang mereka alami secara individual. Agar anak memiliki potensi yang optimal anak seharusnya diberikan stimulasi yang baik sejak mereka dini.

Pendidikan juga merupakan wahana yang sangat fundamental dalam memberikan kerangka dasar terbentuk dan berkembangnya dasar-dasar pengetahuan, sikap dan keterampilan pada anak (Sujiono,2009:2). Untuk itu agar pertumbuhan serta perkembangan anak tercapai secara optimal maka dibutuhkan kondisi serta situasi yang baik pada saat memberikan stimulasi pendidikan yang 
sesuai dengan kebutuhan dan minat anak. Dalam proses pendidikan anak usia dini, anak-anak dikenalkan dan dilatih untuk dapat mengungkapkan pikiran serta perasaannya ke dalam bentuk tindakan dan perilaku yang positif dengan mengembangkan seluruh aspek perkembangan anak. Menurut Catron dan Allen (dalam Sujiono:2009:62-63) terdapat enam aspek perkembangan anak usia dini, yaitu kesadaran personal, kesehatan emosional, sosialisasi, komunikasi, kognisi, dan keterampilan motorik.

Salah satu aspek perkembangan yang perlu dikembangkan pada anak yaitu perkembangan fisik motorik. Perkembangan fisik-motorik adalah perkembangan jasmaniah melalui kegiatan pusat saraf, urat saraf, dan otot yang terkoordinasi. Gerak ini berasal dari perkembangan refleks dan kegiatan yang telah ada sejak lahir (Suyadi, 2010:67). Seorang anak usia dini dapat belajar dan melakukan suatu hal apabila kebutuhan fisik mereka terpenuhi dengan baik, sehingga pertumbuhan dan perkembangan mereka berjalan dengan seimbang. Pada masa anak usia dini, keinginan bergerak mereka lebih banyak dan sangat aktif, sehingga sangat diperlukannya arahan serta bimbingan bagi mereka. Ketika fisik anak berkembang dengan baik, maka perkembangan mereka yang lain akan berkembang dengan baik pula. Selain itu, memungkinkan anak untuk lebih mengeksplor dan mengembangkan keterampilan fisik di lingkungannya dengan bantuan atau tanpa bantuan orang lain.

Perkembangan fisik anak juga berdampingan dengan perkembangan motorik, baik motorik kasar maupun motorik halus. Perkembangan kemampuan motorik dapat memberikan anak kesempatan yang luas untuk bergerak, menemukan pengalaman belajar atau aktivitas sensori motorik yang meliputi penggunaan otot besar maupun otot kecil yang memungkinkan untuk memenuhi perkembangan perseptual motorik anak (Catron dan Allen dalam Sujiono,2009:63).

Aktivitas fisik-motorik anak dapat dikenalkan melalui berbagai kegiatan yang bervariasai dan bermacam-macam, sehingga mereka akan lebih merasa ceria, senang dan aktif dalam mengikuti kegiatan tersebut. Mulai dari aktivitas seperti melompat, meloncat, berjalan dan melempar, serta aktivitas lain yang dirancang untuk mengembangkan potensi fisik-motorik anak. salah satu kegiatan yang dapat mengembangkan potensi fisik-motork anak yaitu kegiatan senam dan menari. Kegiatan ini dapat melatih kedisiplinan dalam mengikuti kegiatan, ketertarikan, kepercayaan diri, kelincahan serta kekuatan dan keserasian antara gerakan dan lagu yang dilakukan.

Kegiatan pembelajaran senam biasanya hanya sekedar senam biasa yang diberikan oleh guru, hanya semata-mata untuk mengawali proses kegiatan belajar mengajar. Padahal kegiatan ssenam ini merupakan suatu awalan anak untuk mengeksplorasi potensi, kreativitas, percaya diri, minat, kelincahan, serta sosialisasi dengan teman. Seharusnya, aktivitas dalam bentuk senam ini dilakukan dengan penuh keceriaan yang muncul dari ekspresi wajah ketika melakukan gerakan senam dengan mengikuti alunan music atau lagu sehingga terjadi sinkronisasi yang indah (Muhyi, dkk, 2016:27). Melalui kegiatan pembelajaran senam guru atau pengajar disekolah akan lebih mudah untuk mengetahui anak-anak yang memiliki ketertarikan, kepercayaan diri, kelincahan serta 
kekuatan dan minat anak dibidang kegiatan yang lainnya seperti menari.

Kegiatan senam yang diberikan guru dapat dikatakan sebagai salah satu upaya mengembangkan potensi kemampuan anak dalam kegiatan menari melalui pendengaran, pengelihatan, olah tubuh, dan irama musik. Selain kegiatan ini juga mudah dipelajari dan dilakukan oleh anak-anak hingga orang tua, dan mampu memperlancar peredaran darah di otak serta dapat membantu konsentrasi dan memperkuat otot tubuh pada anak-anak. Mengingat pentingnya pengembangan gerak bagi anak sebagai pembentukan generasi muda yang berprestasi, berkualitas dan berkarakter, maka upaya memfasilitassi kebutuhan anak-anak bangsa dalam pengembangan geraknya, seperti menyedikan berbagai macam media atau alat dan memberikan kesempatan untuk mencoba berbagai cara memainkannya, adalah merupakan tugas dan tanggungjawab bersama pemerintah, masyarakat dan keluarga.

Kegiatan pengembangan fisik-motorik pada anak dilakukan dengan melakukan kegiatan olah tubuh secara terkoordinasi untuk melatih kelenturan, keseimbangan, dan kelincahan serta melakukan koordinasi gerakan mata-kaki-tangankepala dalam menirukan tarian atau senam.

Kegiatan senam dan menari merupakan salah satu bentuk koordinasi yang dapat menstimulasi gerak tubuh anak seperti koordinasi antara tangan, kaki dan kepala. Koordinasi gerak antara ketiganya sangat diperlukan dalam perkembangan fisik motorik anak. Dalam gerak koordinasi ini, terdapat aspek kelincahan, ketangkasan, keberanian, ketepatan dan kecermatan serta keserasian antara gerak dan lagu. Pada umumnya, anak usia dini sedang berada dalam masa perkembangan koordinasi gerak.

Berdasarkan beberapa laporan penelitian terdahulu seperti yang dilakukan oleh (1) Siagawati (2013) mengenai "Meningkatkan Koordinasi Gerak Kaki, Tangan dan Kepala Anak Melalui Kegiatan Gerak Berirama pada Kelompok B TK Dharmawanita Kwaraan Lendah Kulon Progo Tahun Ajaran 20112/2013” dari Universitas Negeri Yogyakarta diketahui bahwa suatu kegiatan gerak berirama dapat meningkatkan kemampuan koordinasi gerak kaki, tangan dan kepala anak. penggunaan gerak dengan irama telah memberikan motivasi anak untuk dapat bergerak dengan lentur dan seimbang. (2) Munawaroh (2015) tentang "Peningkatan Keterampilan motorik Kasar Melalui Kegiatan Menari Animal Dance Pada Anak Kelompok A Di TK ABA Kutu Asem Yogyakarta" dari Universitas Negeri Surabaya" dapat diketahui bahwa motorik kasar anak dapat ditingkatkan melalui kegiatan menari animal dance, kegiatan menari animal dance ini dilakukan secara berkelanjutan dengan gerakan meloncat, melompat, mengepakkan tangan dan gerakan lainnya yang dilakukan anak sehingga anak lebih antusias dalam mengikuti kegiatan dan keterampilan motorik kasarnya berkembang sangat baik.

Atas dasar empiris tersebut maka dipandang perlu perkembangan gerak anak ini harus dikembangkan dengan cara kegiatan yang bervariasai dan menyenangkan bagi anak seperti kegiatan senam. Melalui kegiatan senam anak diharapkan dapat memiliki kemampuan yang baik di bidang kegiatan yang lain seperti menari. 
Penelitian ini bertujuan mengetahui hubungan kemampuan senam dengan kemampuan menari pada anak kelompok B TK Aisyiyah Bustanul Athfal 57 Surabaya. Rumusan masalah yang akan dijawab adalah: "Apakah kemampuan senam berhubungan dengan kemampuan menari pada anak kelompok B TK Aisyiyah Bustanul Athfal 57 Surabaya?"

Penelitian ini juga diharapkan memberikan kontribusi manfaat bagi khazanah ilmu pengetahuan dan pengembangan pendidikan anak usia dini.

\section{METODE PENELITIAN}

Penelitian ini menggunakan pendekatan kuantitatif dengan desain penelitian korelasional. Pendekatan kuantitatif merupakan salah satu upaya pencarian ilmiah (Scientific Inquiry) yang didasari oleh filsafat positivisme logikal (logical Positivism) yang beroperasi dengan aturan-aturan yang ketat mengenai logika, kebenaran, hukumhukum, dan prediksi (Watson dalam Dharma, 2008:17). Sedangkan menurut Arikunto (2013:122) Cross Sectional yaitu gabungan antara model a dan $b$, untuk memperoleh data yang lebih lengkap yang dilakukan dengan cepat, sekaligus dapat menggambarkan perkembangan individu selama dalam masa pertumbuhan karena mengalami subjek dari berbagai tingkat umur.

Penelitian korelasi juga disebut sebagai penelitian hubungan atau penelitian asosiatif untuk mengetahui hubungan anatar dua variabel atau lebih dengan mengukur koefisiensi atau signifikan dengan menggunakan statistik (Musfiqon dalam Insani, 2013:30).

Hubungan antar variabel dapat digambarkan sebagai berikut.

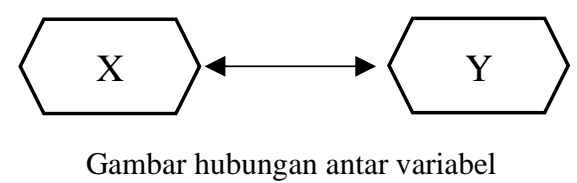

Keterangan :

$X$ : Variabel $X$ atau kemampuan senam

Y : Variabel Y atau kemampuan menari

Subyek penelitian ini adalah seluruh peserta didik usia dini kelompok B TK Aisyiyah Bustanul Athfal 57 Surabaya sebanyak 20 anak.

Indikator variabel yang diteliti adalah kecepatan gerak, kelincahan, kelenturan dan keserasian gerak dengan irama.

Data dikumpulkan dengan metode observasi partisipatif, dan dianalisis dengan teknik analisis korelasi product moment dengan rumus:

$$
r_{x y}=\frac{\sum x y}{\left.\sqrt{(} \sum x^{2}\right)\left(\sum y^{2}\right)}
$$

\section{HASIL PENELITIAN}

Perbedaan hasil observasi sebanyak 8 (delapan) kali pengamatan pada setiap variabel dari subyek penelitian tergambar pada tabel 1 berikut.

Tabel 1. Rerata hasil kemampuan bersenam dan kemampuan menari dari subyek penelitian.

\begin{tabular}{ccc}
\hline Subyek & $\begin{array}{c}\text { Kemampuan } \\
\text { senam }\end{array}$ & $\begin{array}{c}\text { Kemampuan } \\
\text { menari }\end{array}$ \\
\hline 1 & 3,594 & 3.625 \\
2 & 3,906 & 3,750 \\
3 & 3,469 & 3,406 \\
4 & 3,688 & 3,688 \\
5 & 3,188 & 3,094 \\
6 & 3,250 & 3,313 \\
7 & 3,594 & 3,281 \\
8 & 3,906 & 3,688 \\
9 & 3,250 & 3,781 \\
10 & 3,031 & 3,000 \\
11 & 3,313 & 3,313 \\
12 & 3,406 & 3,219 \\
13 & 3,656 & 3,625 \\
14 & 3,563 & 3,563 \\
15 & 3,250 & 3,281 \\
16 & 3,281 & 3,250 \\
17 & 3,281 & 3,313 \\
18 & 3,375 & 3,406 \\
19 & 3,625 & 3,563 \\
20 & 3,406 & 3,313 \\
\hline Rerata & 3,526 & 3,273 \\
\hline
\end{tabular}


Tabel 2. Ringkasan Hasil Uji hipotesis.

\begin{tabular}{llllll}
\hline \multicolumn{1}{c}{ Hipotesis } & Sig & rhit & rtab & H0 & Ha \\
\hline Ada & 0,005 & 0,973 & 0,5227 & ditolak & diterima \\
hubungan & 0,001 & & 0,5368 & & \\
antara & & & & & \\
kemampuan & & & & & \\
bersenam & & & & & \\
dengan & & & & & \\
kemampuan & & & & & \\
menari & & & & & \\
\hline
\end{tabular}

Dari tabel di atas dapat diketahui bahwa nila $r_{\text {hitung }}$ lebih besar daripada indeks $r_{\text {tabel }}$ pada kedua taraf signifikansi tersebut. Dengan demikian maka hipotesis nol $\left(\mathrm{h}_{0}\right)$, dan hipotesis kerja $\left(\mathrm{H}_{\mathrm{a}}\right)$ diterima karena terbukti secara signifikan. Artinya ada hubungan antara kemampuan bersenam dengan kemampuan menari.

Bagaimana tingkat korelasi antara kedua kemampuan tersebut? Untuk menginterpretasi tingkat hubungan kedua variabel digunakan tabel interpretasi nilai $r$ sebagai berikut.

Tabel 3. Tabel Interpretasi Nilai $r$

\begin{tabular}{lc}
\hline \multicolumn{1}{c}{ Besarnya nilai $\mathbf{r}$} & Interpretasi \\
\hline Antara 0,800 sampai dengan 1,00 & Tinggi \\
Antara 0,600 sampai dengan 0,800 & Cukup \\
Antara 0,400 sampai dengan 0,600 & Agak rendah \\
Antara 0,200 sampai dengan 0,400 & Rendah \\
Antara 0,000 sampai dengan 0,200 & Sangat rendah \\
\hline
\end{tabular}

(Sumber: Sutrisno Hadi dalam Arikunto, 2013:319)

Berdasarkan tabel tersebut dimana nilai $\mathrm{r}_{\text {hit }}=$ 0.973 berada pada rentang antara 0,800 sampai dengan 1,00. Berarti tingkat korelasi kedua variabel tersebut masuk dalam kategori tingkat korelasi tinggi. Dengan demikian dapat dikatakan bahwa sangat kuat hubungan antara kemampuan senam dengan kemampuan menari. Artinya jika kemampuan senam semakin tinggi maka kemampuan menari juga semakin tinggi.

\section{PEMBAHASAN}

Berdasarkan indikator perkembangan anak yang diteliti antara lain melakukan gerakan tubuh secara terkoordinasi untuk melatih ketepatan gerakan, kelincahan gerakan, kelenturan tubuh, keserasian gerak dengan irama, dari hasil penelitian ini dapat dikatakan bahwa kemampuan motorik senam sangat menunjang kemampuan menari pada anak. Karena hubungan kedua variabel adalah hubungan simetris, jika variabel yang satu meningkat maka variabel yang lain juga meningkat. Dalam hal ini jika kemampuan motorik senam tinggi maka kemampuan motorik menari juga tinggi.

Secara rinci pembahasan lengkapnya sebagai berikut.

Dari data yang terkumpul dan dari hasil perhitungan data setiap observasi, dapat diketahui bahwa adanya hubungan antara kemampuan senam dengan kemampuan menari. Hal ini terbukti pada observasi 1 dari 20 anak pada variabel $\mathrm{x}$ yaitu kemampuan senam pada indikator (1) Melakukan gerakan tubuh secara terkoordinasi untuk melatih ketepatan gerakan, anak yang mulai berkembang ada 5 anak, berkembang sesuai harapan 12 anak dan berkembang sangat baik 3 anak. pada indikator (2) Melakukan gerakan tubuh secara terkoordinasi untuk melatih kelincahan gerakan, anak yang mulai berkembang 4 anak, berkembang sesuai harapan 7 anak dan berkembang sangat baik 9 anak. Pada indikator (3) Melakukan gerakan tubuh secara terkoordinasi untuk melatih kelenturan tubuh, anak yang mulai berkembang ada 4 anak, berkembang sesuai harapan 9 anak dan berkembang sangat baik ada 7 anak. Dan pada indikator (4) Melakukan gerakan tubuh secara terkoordinasi untuk melatih keserasian gerak dengan irama, anak yang mulai berkembang 5 anak, berkembang sesuai harapan 12 anak dan berkembang sangat baik 3 anak. 
Sedangkan hasil dari variabel y yaitu kemampuan menari pada indikator (1) Melakukan gerakan tubuh secara terkoordinasi untuk melatih ketepatan gerakan, anak yang mulai berkembang ada 10 anak, berkembang sesuai harapan 8 anak dan berkembang sangat baik 2 anak. Pada indikator (2) Melakukan gerakan tubuh secara terkoordinasi untuk melatih kelincahan gerakan, anak dan yang mulai berkembang 6 anak, berkembang sesuai harapan 14 anak. Pada indikator (3) Melakukan gerakan tubuh secara terkoordinasi untuk melatih kelenturan tubuh, anak yang mulai berkembang ada 9 anak, berkembang sesuai harapan 10 anak dan berkembang sangat baik ada 1 anak. Dan pada indikator (4) Melakukan gerakan tubuh secara terkoordinasi untuk melatih keserasian gerak dengan irama, anak yang mulai berkembang 4 anak, berkembang sesuai harapan 14 anak dan berkembang sangat baik 2 anak.

Pada observasi 2 dari 20 anak pada variabel $\mathrm{x}$ yaitu kemampuan senam pada indikator (1) Melakukan gerakan tubuh secara terkoordinasi untuk melatih ketepatan gerakan, anak yang mulai berkembang ada 5 anak, berkembang sesuai harapan 10 anak dan berkembang sangat baik 5 anak. pada indikator (2) Melakukan gerakan tubuh secara terkoordinasi untuk melatih kelincahan gerakan, anak yang mulai berkembang 1 anak, berkembang sesuai harapan 11 anak dan berkembang sangat baik 8 anak. Pada indikator (3) Melakukan gerakan tubuh secara terkoordinasi untuk melatih kelenturan tubuh, anak yang mulai berkembang ada 6 anak, berkembang sesuai harapan 9 anak dan berkembang sangat baik ada 5 anak. Dan pada indikator (4) Melakukan gerakan tubuh secara terkoordinasi untuk melatih keserasian gerak dengan irama, anak yang mulai berkembang 5 anak, berkembang sesuai harapan 14 anak dan berkembang sangat baik 1 anak.

Sedangkan hasil dari variabel y yaitu kemampuan menari pada indikator (1) Melakukan gerakan tubuh secara terkoordinasi untuk melatih ketepatan gerakan, anak yang mulai berkembang ada anak dan berkembang sesuai harapan anak. Pada indikator (2) Melakukan gerakan tubuh secara terkoordinasi untuk melatih kelincahan gerakan, anak dan yang mulai berkembang anak, berkembang sesuai harapan 1anak dan berkembang sangat baik anak. Pada indikator (3) Melakukan gerakan tubuh secara terkoordinasi untuk melatih kelenturan tubuh, anak yang mulai berkembang ada anak, berkembang sesuai harapan anak dan berkembang sangat baik ada anak. Dan pada indikator (4) Melakukan gerakan tubuh secara terkoordinasi untuk melatih keserasian gerak dengan irama, anak yang mulai berkembang anak dan berkembang sesuai harapan anak.

Pada observasi 3 dari 20 anak pada variabel x yaitu kemampuan senam pada indikator (1) Melakukan gerakan tubuh secara terkoordinasi untuk melatih ketepatan gerakan, anak yang mulai berkembang ada 2 anak, berkembang sesuai harapan 14 anak dan berkembang sangat baik 4 anak. pada indikator (2) Melakukan gerakan tubuh secara terkoordinasi untuk melatih kelincahan gerakan, anak yang mulai berkembang 2 anak, berkembang sesuai harapan 11 anak dan berkembang sangat baik 7 anak. Pada indikator (3) Melakukan gerakan tubuh secara terkoordinasi untuk melatih kelenturan tubuh, anak yang mulai berkembang ada 1 anak, berkembang sesuai harapan 14 anak dan berkembang sangat baik ada 5 
anak. Dan pada indikator (4) Melakukan gerakan tubuh secara terkoordinasi untuk melatih keserasian gerak dengan irama, anak yang mulai berkembang 2 anak, berkembang sesuai harapan 16 anak dan berkembang sangat baik 2 anak.

Sedangkan hasil dari variabel y yaitu kemampuan menari pada indikator (1) Melakukan gerakan tubuh secara terkoordinasi untuk melatih ketepatan gerakan, anak yang mulai berkembang ada 1 anak, berkembang sesuai harapan 17 anak dan berkembang sangat baik 2 anak. Pada indikator (2) Melakukan gerakan tubuh secara terkoordinasi untuk melatih kelincahan gerakan, anak dan yang mulai berkembang 1anak, berkembang sesuai harapan 10 anak dan berkembang sangat baik 9 anak. Pada indikator (3) Melakukan gerakan tubuh secara terkoordinasi untuk melatih kelenturan tubuh, anak yang mulai berkembang ada 1 anak, berkembang sesuai harapan 11 anak dan berkembang sangat baik ada 8 anak. Dan pada indikator (4) Melakukan gerakan tubuh secara terkoordinasi untuk melatih keserasian gerak dengan irama, anak yang mulai berkembang 1 anak, berkembang sesuai harapan 13 anak dan berkembang sangat baik 6 anak.

Pada observasi 4 dari 20 anak pada variabel x yaitu kemampuan senam pada indikator (1) Melakukan gerakan tubuh secara terkoordinasi untuk melatih ketepatan gerakan, anak yang mulai berkembang ada 1 anak, berkembang sesuai harapan 13 anak dan berkembang sangat baik 6 anak. pada indikator (2) Melakukan gerakan tubuh secara terkoordinasi untuk melatih kelincahan gerakan, anak yang mulai berkembang 1 anak, berkembang sesuai harapan 7 anak dan berkembang sangat baik 12 anak. Pada indikator (3) Melakukan gerakan tubuh secara terkoordinasi untuk melatih kelenturan tubuh, anak yang mulai berkembang ada 1 anak, berkembang sesuai harapan 6 anak dan berkembang sangat baik ada 13 anak. Dan pada indikator (4) Melakukan gerakan tubuh secara terkoordinasi untuk melatih keserasian gerak dengan irama, anak yang mulai berkembang 1 anak, berkembang sesuai harapan 7 anak dan berkembang sangat baik 12 anak.

Sedangkan hasil dari variabel y yaitu kemampuan menari pada indikator (1) Melakukan gerakan tubuh secara terkoordinasi untuk melatih ketepatan gerakan, anak yang mulai berkembang ada 1 anak, berkembang sesuai harapan 10 anak dan berkembang sangat baik 9 anak. Pada indikator (2) Melakukan gerakan tubuh secara terkoordinasi untuk melatih kelincahan gerakan, anak dan yang mulai berkembang 1 anak, berkembang sesuai harapan 7 anak dan berkembang sangat baik 12 anak. Pada indikator (3) Melakukan gerakan tubuh secara terkoordinasi untuk melatih kelenturan tubuh, anak yang mulai berkembang ada 1 anak, berkembang sesuai harapan 9 anak dan berkembang sangat baik ada 10 anak. Dan pada indikator (4) Melakukan gerakan tubuh secara terkoordinasi untuk melatih keserasian gerak dengan irama, anak yang mulai berkembang 1 anak, berkembang sesuai harapan 6 anak dan berkembang sangat baik 13 anak.

Pada observasi 5 dari 20 anak pada variabel x yaitu kemampuan senam pada indikator (1) Melakukan gerakan tubuh secara terkoordinasi untuk melatih ketepatan gerakan, anak yang mulai berkembang ada 1 anak, berkembang sesuai harapan 11 anak dan berkembang sangat baik 8 anak. Pada indikator (2) Melakukan gerakan tubuh 
secara terkoordinasi untuk melatih kelincahan gerakan, anak yang mulai berkembang 1 anak, berkembang sesuai harapan 8 anak dan berkembang sangat baik 11 anak. Pada indikator (3) Melakukan gerakan tubuh secara terkoordinasi untuk melatih kelenturan tubuh, anak yang mulai berkembang ada 1 anak, berkembang sesuai harapan 13 anak dan berkembang sangat baik ada 6 anak. Dan pada indikator (4) Melakukan gerakan tubuh secara terkoordinasi untuk melatih keserasian gerak dengan irama, anak yang mulai berkembang 1 anak, berkembang sesuai harapan 6anak dan berkembang sangat baik 13 anak.

Sedangkan hasil dari variabel y yaitu kemampuan menari pada indikator (1) Melakukan gerakan tubuh secara terkoordinasi untuk melatih ketepatan gerakan, anak yang mulai berkembang ada 1 anak, berkembang sesuai harapan 6 anak dan berkembang sangat baik 13 anak. Pada indikator (2) Melakukan gerakan tubuh secara terkoordinasi untuk melatih kelincahan gerakan, anak dan yang mulai berkembang lanak, berkembang sesuai harapan 7 anak dan berkembang sangat baik 12 anak. Pada indikator (3) Melakukan gerakan tubuh secara terkoordinasi untuk melatih kelenturan tubuh, anak yang mulai berkembang ada 1 anak, berkembang sesuai harapan 12 anak dan berkembang sangat baik ada 7 anak. Dan pada indikator (4) Melakukan gerakan tubuh secara terkoordinasi untuk melatih keserasian gerak dengan irama, anak yang mulai berkembang 1 anak, berkembang sesuai harapan 1 anak dan berkembang sangat baik 18 anak.

Pada observasi 6 dari 20 anak pada variabel x yaitu kemampuan senam pada indikator (1) Melakukan gerakan tubuh secara terkoordinasi untuk melatih ketepatan gerakan, anak yang mulai berkembang ada 1 anak, berkembang sesuai harapan 9 anak dan berkembang sangat baik 10 anak. pada indikator (2) Melakukan gerakan tubuh secara terkoordinasi untuk melatih kelincahan gerakan, anak yang mulai berkembang lanak, berkembang sesuai harapan 5 anak dan berkembang sangat baik 14 anak. Pada indikator (3) Melakukan gerakan tubuh secara terkoordinasi untuk melatih kelenturan tubuh, anak yang berkembang sesuai harapan 7 anak dan berkembang sangat baik ada 13 anak. Dan pada indikator (4) Melakukan gerakan tubuh secara terkoordinasi untuk melatih keserasian gerak dengan irama, anak yang berkembang sesuai harapan 10 anak dan berkembang sangat baik 10 anak.

Sedangkan hasil dari variabel y yaitu kemampuan menari pada indikator (1) Melakukan gerakan tubuh secara terkoordinasi untuk melatih ketepatan gerakan, anak yang mulai berkembang ada 3 anak, berkembang sesuai harapan 11 anak dan berkembang sangat baik 6 anak. Pada indikator (2) Melakukan gerakan tubuh secara terkoordinasi untuk melatih kelincahan gerakan, anak dan yang mulai berkembang 2 anak, berkembang sesuai harapan 5 anak dan berkembang sangat baik 13 anak. Pada indikator (3) Melakukan gerakan tubuh secara terkoordinasi untuk melatih kelenturan tubuh, anak berkembang sesuai harapan 8 anak dan berkembang sangat baik ada 18 anak. Dan pada indikator (4) Melakukan gerakan tubuh secara terkoordinasi untuk melatih keserasian gerak dengan irama, anak yang mulai berkembang 3 anak, berkembang sesuai harapan 5 anak dan berkembang sangat baik 12 anak. 
Pada observasi 7 dari 20 anak pada variabel x yaitu kemampuan senam pada indikator (1) Melakukan gerakan tubuh secara terkoordinasi untuk melatih ketepatan gerakan, anak berkembang sesuai harapan 6 anak dan berkembang sangat baik 14 anak. Pada indikator (2) Melakukan gerakan tubuh secara terkoordinasi untuk melatih kelincahan gerakan, anak berkembang sesuai harapan 9 anak dan berkembang sangat baik 11 anak. Pada indikator (3) Melakukan gerakan tubuh secara terkoordinasi untuk melatih kelenturan tubuh, anak yang mulai berkembang ada 1 anak, berkembang sesuai harapan 8 anak dan berkembang sangat baik ada 11 anak. Dan pada indikator (4) Melakukan gerakan tubuh secara terkoordinasi untuk melatih keserasian gerak dengan irama, anak yang mulai berkembang 1 anak, berkembang sesuai harapan 8 anak dan berkembang sangat baik 11 anak.

Sedangkan hasil dari variabel y yaitu kemampuan menari pada indikator (1) Melakukan gerakan tubuh secara terkoordinasi untuk melatih ketepatan gerakan, anak yang berkembang sesuai harapan 5 anak dan berkembang sangat baik 15 anak. Pada indikator (2) Melakukan gerakan tubuh secara terkoordinasi untuk melatih kelincahan gerakan, anak dan yang mulai berkembang 2 anak, berkembang sesuai harapan 8 anak dan berkembang sangat baik 11 anak. Pada indikator (3) Melakukan gerakan tubuh secara terkoordinasi untuk melatih kelenturan tubuh, anak yang mulai berkembang ada 2 anak, berkembang sesuai harapan 8 anak dan berkembang sangat baik ada 10 anak. Dan pada indikator (4) Melakukan gerakan tubuh secara terkoordinasi untuk melatih keserasian gerak dengan irama, anak yang mulai berkembang 2 anak, berkembang sesuai harapan 9 anak dan berkembang sangat baik 9anak.

Pada observasi 8 dari 20 anak pada variabel $\mathrm{x}$ yaitu kemampuan senam pada indikator (1) Melakukan gerakan tubuh secara terkoordinasi untuk melatih ketepatan gerakan, anak yang berkembang sesuai harapan 7 anak dan berkembang sangat baik 13 anak. Pada indikator (2) Melakukan gerakan tubuh secara terkoordinasi untuk melatih kelincahan gerakan, anak yang berkembang sesuai harapan 11 anak dan berkembang sangat baik 9 anak. Pada indikator (3) Melakukan gerakan tubuh secara terkoordinasi untuk melatih kelenturan tubuh, anak yang berkembang sesuai harapan 8 anak dan berkembang sangat baik ada 12 anak. Dan pada indikator (4) Melakukan gerakan tubuh secara terkoordinasi untuk melatih keserasian gerak dengan irama, anak yang berkembang sesuai harapan 9 anak dan berkembang sangat baik 11 anak.

Sedangkan hasil dari variabel y yaitu kemampuan menari pada indikator (1) Melakukan gerakan tubuh secara terkoordinasi untuk melatih ketepatan gerakan, anak yang mulai berkembang ada 2 anak, berkembang sesuai harapan 8 anak dan berkembang sangat baik 10 anak. Pada indikator (2) Melakukan gerakan tubuh secara terkoordinasi untuk melatih kelincahan gerakan, anak yang berkembang sesuai harapan 9 anak dan berkembang sangat baik 11 anak. Pada indikator (3) Melakukan gerakan tubuh secara terkoordinasi untuk melatih kelenturan tubuh, anak yang mulai berkembang ada 2 anak, berkembang sesuai harapan 5 anak dan berkembang sangat baik ada 13 anak. Dan pada indikator (4) Melakukan gerakan tubuh secara terkoordinasi untuk melatih keserasian gerak 
dengan irama, anak yang berkembang sesuai harapan 12 anak dan berkembang sangat baik 8 anak.

Hasil penelitian ini sejalan dengan hasil penelitian Siagawati dan hasil peneltian Munawaroh seperti yang sudah dikemukakan pada pendahuluan artikel ini. Hasil serupa juga ditunjukkan oleh hasil penelitian Prihartini (2016) bahwa kegiatan senam menekankan pada anak berpartisipasi untuk menggerakkan seluruh tubuhnya sehingga anak akan aktif mengikuti gerakan-gerakan senam dengan diiringi irama. Semakin banyak kegiatan yang bervariatif dan inovatif yang diberikan guru, semakin banyak pula peluang kecerdasan yang akan dimiliki anak, anak akan terasah dan dapat berkembang dengan baik. Selain itu anak juga tidak akan mudah bosan atau malas mengikuti kegiatan yang diberikan guru saat di sekolah.

\section{SIMPULAN DAN SARAN}

\subsection{Simpulan}

Berdasarkan hasil pengujian hipotesis dapat dinyatakan bahwa ada hubungan kemampuan bersenam dengan kemampuan menari pada anak usia dini kelompok usia 5-6 tahun. Kategori korelasi antar variabelnya adalah masuk dalam kategori korelasi tinggi. Dengan demikian dapat dikatakan bahwa ada hubungan yang kuat antara kemampauan senam dengan menari. Hal ini dapat diartikan bahwa semakin bagus kemampuan bersenam anak maka semakin bagus pula kemampuan menarinya.

\subsection{Saran}

Berdasarkan hasil penelitian yang telah dilakukan dapat disarankan:

1. Bagi Pihak Sekolah
Diharapkan penelitian ini memberikan masukan kepada pihak sekolah terutama kepada guru. Dalam hal ini penerapann pembelajaran senam dan menari harus selalu mengembangkan cara serta proses belajar yang menyenang,kan bagi anak sehingga anak termotivasi untuk melakukan setiap kegiatan tanpa paksaan dari siapapun. Serta diharapkan agar pihak sekolah lebih mengemnbangkan potensi-potensi yang dimiliki anak sesuai bakat, minat serta kebutuhan setiap anak.

\section{Bagi Orang tua}

Diharapkan bagi orangtua untuk memberikan motivasi yang positif dan selalu memantau setiap perkembangan anak. Serta selalu memberikan waktu bersama anak, karena waktu kebersamaan dengan orangtua itu sangat berharga bagi anak. Anak akan merasa aman serta merasa dirinya ada untuk orangtua sehingga mereka mampu mengerjakan apa yang ingin dilakukan sesuai keinginannya.

\section{REFERENSI}

Arikunto, Suharsimi. (2013). Prosedur Penelitian Suatu Pendekatan Praktik. Jakarta: PT Rineka Cipta

Dharma, Surya. (2008). Pendekatan, Jenis dan Metode Penelitian Pendidikan. Jakarta: Direktorat Tenaga Kependidikan.

Insani, Aulia. (2013). Hubungan Kemampuan Senam dengan Kemampuan Kognitif Siswa Kelompok B TK Kemala Bhayangkari I Surabaya. Surabaya: Skripsi Program Studi PGPAUD Fakultas Keguruan dan Ilmu Pendidikan Universitas PGRI Adi Buana Surabaya. Tidak dipublikasikan.

Muhyi, Muhammad., dkk. (2017). Learning Trough Movement Senam Bugar Cerdas Ceria Berkarakter (Senam BCCB). Yogyakarta: $\mathrm{CV}$. Andi Offset.

Munawaroh, Kurnia. (2015). Peningkatan Keterampilan Motorik Kasar Melalui Kegiatan Menari Animal Dance Pada Anak 
Kelompok A Di TK ABA Kutu Asem Yogyakarta. Skripsi PGPAUD Universitas Negeri Surabaya.

Prihantini, Ratna. (2016). Pengaruh Kegiatan Senam Terhadap Kecerdasan Kinestetik Anak Kelompok A Di TK Pertiwi II Metuk. Surakarta: PGPAUD Universitas Muhammadiyah Surakarta.

Siagawati, Myka. (2013). Meningkatkan Koordinasi Kaki, Tangan Dan Kepala Anak Melalui Kegiatan Gerak Berirama Pada Kelompok B TK Dharmawanita Kwaraan Lendah Kulon Progo Tahun Ajaran 2012/2013. Yogyakarta: Skripsi PGPAUD Universitas Negeri Yogyakarta.

Sujiono, Yuliani Nurani. (2009). Konsep Dasar Pendidikan Anak Usia Dini. Jakarta Barat: PT Index Permata Puri Media.

Suyadi. (2010). Psikologi Belajar Pendidikan Anak Usia Dini. Yogyakarta:PT Pustaka Insan Madani. 